\title{
A Survey of High Performance Concrete Developments in Civil Engineering Field
}

\author{
Vatsal Patel $^{1}$, Niraj Shah ${ }^{2}$ \\ ${ }^{1}$ G. H. Patel College of Engineering \&Technology, Gujarat Technological University, Ahmedabad, India \\ ${ }^{2}$ C. S. Patel Institute of Engineering \& Technology, Charotar University of Science and Technology, Changa, India \\ Email: vatsalnpatel@yahoo.com,nirajshah.cv@ecchanga.ac.in
}

Received March 30, 2013; revised May 2, 2013; accepted May 10, 2013

Copyright (C) 2013 Vatsal Patel, Niraj Shah. This is an open access article distributed under the Creative Commons Attribution License, which permits unrestricted use, distribution, and reproduction in any medium, provided the original work is properly cited.

\begin{abstract}
High Performance concrete (HPC) has received increased attention in the development of infrastructure Viz., Buildings, Industrial Structures, Hydraulic Structures, Bridges and Highways etc. leading to utilization of large quantity of concrete. This paper presents a comprehensive coverage of High Performance concrete developments in civil engineering field. It highlights the High Performance concrete features and requirements over conventional concrete. Furthermore, recent trends with regard to High Performance Concrete development in this area are explored. This paper also includes effect of Mineral and Chemical Admixtures used to improve performance of concrete.
\end{abstract}

Keywords: Chemical Admixtures; Conventional Concrete; High Performance Concrete; Mineral Admixtures

\section{Introduction}

Concrete is the most widely used construction material in India with annual consumption exceeding 100 million cubic metres. Conventional Ordinary Portland Cement Concrete which is designed on the basis of compressive strength does not meet many functional requirements as it is found deficit in aggressive environments, time of construction, energy absorption capacity, repair and retrofitting jobs etc. So, there is a need to design High Performance Concrete which is far superior to conventional concrete as the Ingredients of High Performance Concrete contribute most efficiently to the various properties. A High Performance Concrete is a concrete in which certain characteristics are developed for a particular application and environment so that it will give excellent performance in the structure in which it will be placed, in the environment to which it will be exposed, and with the loads to which it will be subjected during its design life [1].

The strategic Highway Research Programme (SHRP) has defined a High Performance Concrete as concrete meeting one of the following requirements:

1) 4 hours compressive strength $\geq 17.5 \mathrm{~N} / \mathrm{mm}^{2}$;

2) 24 hours compressive strength $\geq 35 \mathrm{~N} / \mathrm{mm}^{2}$;

3) 28 days compressive strength $\geq 70 \mathrm{~N} / \mathrm{mm}^{2}$;

4) Water cement ratio $\leq 0.35$;

5) Durability factor $>80$ after 300 cycles of freezing and thawing.
High Performance Concrete is also defined as concrete which meets special performance and uniformity requirements that cannot be always achieved routinely by using conventional materials and normal mixing, placing and curing practices [2]. The requirements may involve enhancement of placement and compaction without segregation, long term mechanical properties, early age strength, volume stability or service life in severe environments. The ingredients generally used in investigations are 1) Cement; 2) Fine Aggregate; 3) Coarse Aggregate; 4) Water; 5) Mineral Admixtures; and 6) Chemical Admixtures [3-74].

\section{Admixture Applications in High Performance Concrete}

Admixtures play an important role in the production of High Performance Concrete. Mineral Admixtures form an essential part of the High Performance Concrete mix. They are used for various purposes depending upon their properties. Table 1 shows different types of mineral admixtures with their particle characteristics. Chemical composition determines the role of mineral admixtures in enhancing properties of concrete. Different materials with Pozzolanic properties such as Fly Ash (FA), Ground Granulated Blast Furnace Slag (GGBS), Silica fume (SF), High Reactivity Metakaolin (HRM), Rice Husk Ash (RHA), Copper Slag, Fine Ground Ceramics have been 
Table 1. Different mineral admixtures used in HPC.

\begin{tabular}{|c|c|c|}
\hline $\begin{array}{l}\text { Mineral } \\
\text { admixtures }\end{array}$ & Classification & Particle characteristics \\
\hline $\begin{array}{l}\text { Ground } \\
\text { granulated blast } \\
\text { furnace slag }\end{array}$ & $t \underset{\text { pozzolanic }}{\text { Cementitious and }}$ & $\begin{array}{l}\text { Unprocessed materials are grain } \\
\text { like sand, ground to size }<45 \mu \mathrm{m} \\
\text { particles and have a rough texture }\end{array}$ \\
\hline Fly ash & $\begin{array}{c}\text { Cementitious and } \\
\text { pozzolanic }\end{array}$ & $\begin{array}{c}\text { Powder consists of particles size } \\
<45 \mu \mathrm{m}, 10 \% \text { to } 15 \% \text { are more than } \\
45 \mu \mathrm{m} \text {, solid spheres and generally } \\
\text { smooth }\end{array}$ \\
\hline Silica fume & $\begin{array}{l}\text { Highly active } \\
\text { pozzolana }\end{array}$ & $\begin{array}{c}\text { Fine powder consisting of solid } \\
\text { spheres of } 0.1 \mu \mathrm{m} \text { average diameter }\end{array}$ \\
\hline Rice husk ash & $\begin{array}{l}\text { Highly active } \\
\text { pozzolana }\end{array}$ & $\begin{array}{l}\text { Particles are }<45 \mu \mathrm{m} \text { in size and } \\
\text { have cellular and porous structure }\end{array}$ \\
\hline
\end{tabular}

widely used as supplementary cementitious materials in the production of High Performance Concrete [3-74]. Such applications not only help to improve the strength and durability characteristics of High Performance Concrete but will also help to dispose more of the industrial by-products which are major environmental threats.

Different Chemical admixtures (Super plasticizers) are extensively used in development of High Performance Concrete with very low water cement ratio are represented in Table 2 with their functions.

\section{Experimental Investigations on High Performance Concrete}

Shannag et al. [2] prepared High Performance Concrete mixes with $\mathrm{W} / \mathrm{B}$ ratio $=0.35$ containing various proportions of natural pozzolan (blend of certain volcanic stuff) $(0 \%, 5 \%, 10 \%, 15 \%$ by weight of cement $)$ and silica fume $\left(0,20,40,60 \mathrm{~kg} / \mathrm{m}^{3}\right)$ with naphthalene formaldehyde sulfonated superplasticizer and checked performance in severe sulphate environments $\left(\mathrm{Na}_{2} \mathrm{SO}_{4}, \mathrm{MgSO}_{4}\right)$ and in Sea Waters. The investigation indicated that the concrete mix containing $15 \%$ natural pozzolan, and 15\% silica fume showed the best protection in sulphates solutions and sea waters by retaining more than $65 \%$ of its Compressive strength after one year of storage. High Performance concrete two way slabs cast with $\mathrm{M}_{60}$ grade concrete with $\mathrm{W} / \mathrm{C}$ ratio $0.32 \%$ and $7.5 \%$ silica fume exhibit good strength than RCC slab [3]. High Performance reinforced concrete columns were manufactured at various replacement levels of silica fume $(0 \%, 5 \%, 7.5 \%$, and $10 \%)$ and flyash (10\%) with superplasticizer CERAPLAST 300 and W/B ratio 0.3 to target a mean strength of $\mathrm{M}_{60}$. The cube compressive strength results at 3 days, 7 days, 28 days, 56days and 90 days indicated that maximum strength was obtained with $5 \% \mathrm{SF}$ and $10 \% \mathrm{FA}$ at all ages [4]. The effect of $\mathrm{Cl}^{-}+\mathrm{SO}_{4}^{2-}$ solution on the compressive strength of HPC mixes was checked by Shakir A. Al-Mishhadani et al. [5]. Results of destructive and non-destructive tests were statistically
Table 2. Different chemical admixtures used in HPC.

\begin{tabular}{|c|c|}
\hline $\begin{array}{l}\text { Chemical } \\
\text { admixtures }\end{array}$ & Function \\
\hline Superplasticizer & $\begin{array}{l}\text { To reduce the water requirement by } 15 \% \text { to } 20 \% \\
\text { without affecting the workability leading to a high } \\
\text { strength and dense concrete }\end{array}$ \\
\hline Accelerator & $\begin{array}{l}\text { To reduce the setting time of concrete thus helping } \\
\text { early removal of forms and therefore used in cold } \\
\text { weather concreting }\end{array}$ \\
\hline Retarder & $\begin{array}{l}\text { To increase the setting time by slowing down the } \\
\text { hydration of cement and therefore are preferred in } \\
\text { places of high temperature concreting }\end{array}$ \\
\hline $\begin{array}{l}\text { Water reducing } \\
\text { admixture }\end{array}$ & $\begin{array}{l}\text { To achieve certain workability (slump) at low water } \\
\text { cement ratio for a specified strength thus saving on } \\
\text { the cement }\end{array}$ \\
\hline $\begin{array}{l}\text { Air entraining } \\
\text { admixture }\end{array}$ & $\begin{array}{l}\text { To entrain small air bubbles in concrete which act } \\
\text { as rollers thus improving the workability and } \\
\text { therefore very effective in freeze-thaw cycles as } \\
\text { they provide a cushioning effect on the expanding } \\
\text { water in the concreting in cold climate }\end{array}$ \\
\hline
\end{tabular}

analyzed by using SPSS verson 15 software and statistical models were proposed to evaluate compressive strength, splitting tensile strength, modulus of rupture and static modulus of elasticity. High Performance Concrete mixes containing different percentages of metakaolin were tested for strength and durability and have shown better resistances to the attacks of chemicals such as chloride and sulphates when exposed to these chemicals for 180 days period [6]. Durability in terms of Chloride ion permeability was measured for metakaolin based High Performance Concrete [7]. Bhanja et al. [8] developed silica fume based high Performance Concrete mixes and found significant improvements in the tensile strength. Durability factor at the end of 30 freezing and thawing cycle of High Performance Concrete samples were examined [9]. Rhelogical properties of High Performance Concrete mixes produced by rice husk ash and fly ash were studied and found that for low yield stress and moderate plastic viscosity, blending of equal masses of silica fume and rice husk ash seems to be a suitable admixture [10]. A. H. Menon et al. [11] studied effect of mineral admixtures like fly ash, ground granulated blast furnace slag, silica fume and chemical admixtures (superplasticizers) on the porosity, pore size distribution and compressive strength development of high strength concrete in seawater curing condition. The High Performance Concrete was prepared by adding tire rubber fibers with composition of concrete at $0.25 \mathrm{~W} / \mathrm{B}$ ratio [12]. The compressive strength at 3 days, 7 days and 28 days was reduced by $20 \%$ for High Performance Concrete with rubber tyre in comparison with control High Performance Concrete. A High Performance Concrete of grade $\mathrm{M}_{30}$ was prepared by replacing cement with ground granulated blast furnace slag $(0 \%, 40 \%, 50 \%, 60 \%)$, sand with robo sand (crusher 
dust) $(0 \%, 5 \%, 10 \%, 15 \%, 20 \%, 25 \%, 30 \%), 1.5 \%$ SAVEMIX SP111 admixture and tested for compressive and tensile strengths at 7 days and 28 days [13]. The percentage increase of compressive strength of concrete is $11.06 \%$ and $17.6 \%$ at the age of 7 and 28 days by replacing $50 \%$ of cement with GGBS and $25 \%$ of sand with ROBO sand. Pazhani et al. [14] produced High Performance Concrete by replacing $20 \%, 40 \%, 60 \%, 80 \%$, $100 \%$ of fine aggregate with copper slag and $30 \%$ of cement with GGBS and tested to assess the durability parameters such as water absorption and chloride ion penetration. The water absorption and chloride ion penetrability for $30 \%$ replacement of cement with GGBS were decreased by $4.58 \%$ and $29.90 \%$ respectively $\&$ for $100 \%$ replacement of fine aggregate with copper slag same were decreased by $33.59 \%$ and $77.32 \%$ respectively. The mechanical and durability properties of different High Performance Concrete mixes containing fly ash were studied and have been used to develop precast concrete products such as non pressure pipes and heavy duty paver blocks and these developments are reported [15]. A. Camoes et al. [16] produced low cost High Performance concrete by replacing fly ash with cement. Workability, Mechanical and durability properties of the produced concrete were studied. Hani H. Nassif et al. [17] evaluated the elastic modulus of high performance concrete made from mixes using various percentages of fly ash, silica fume and granulated blast furnace slag. The effect of curing methods namely air-dry curing, curing compound and wet curing with burlap on the elastic modulus was also studied. An experimental work was carried out regarding the basic physical characteristics, mechanical and fracture-mechanics properties, durability charecteristics, hydric and thermal properties of high performance concrete with upto $60 \%$ of Portland cement replaced by fine ground ceramics [18]. K. E. Hassan et al. [19] carried laboratory study on the properties of superplasticised high performance concrete by using SF and FA $(10 \%, 30 \%$ by weight of cement). The SF concrete showed similar strength development to that of the Ordinary Portland Cement concrete but slight higher values at all tested ages (1, 3, 7, 28, 365 days). FA concrete gave lowest compressive strength at early ages, same at 28 days and higher at 365 days than OPC concrete. SF and FA reduced the permeability by $87 \%$ and $84 \%$ respectively in the long term (365 days). A study was carried out on the properties of Portland cement concrete (PCC), High volume fly ash concrete (HFAC, containing $40 \%$ of FA) and concrete (GGFAC, containing a combination of $25 \%$ FA and 15\% GGBS) by assessing compressive strength and resistance to $\mathrm{H}_{2} \mathrm{SO}_{4}$ attack. The compressive strength of GGFAC increased by $23.3 \%$, higher than that of PCC, but lower than that of HFAC between 28 days and 1 year.The compressive strength of GGFAC and
HFAC increased with increasing immersion period in $\mathrm{H}_{2} \mathrm{SO}_{4}$ solution. The combination of FA and GGBS improved both short and long term properties of concrete, while HFAC requires a relatively longer time to get its beneficial effect [20]. Abhilash Shukla et al. [21] evaluated the optimum percentage $(0 \%, 5 \%, 10 \%, 15 \%$, and $20 \%$ ) of Rice Husk Ash as a partial replacement of cement for $\mathrm{M}_{30}$ and $\mathrm{M}_{60}$ grade of concrete. There was a significant improvement in compressive strength (3\% to $10 \%$ increase) and flexural strength ( $0.6 \%$ to $8 \%$ increase) of the concrete with rice husk content of $10 \%$ for $\mathrm{M}_{30}$ and $\mathrm{M}_{60}$ grade concrete at 7 days and 28 days. By using linear regression technique M. F. Zain et al. [22] suggested formulae that relate splitting tensile strength with that of compressive strength, W/B ratio and concrete age for High Performance Concrete. The STS values obtained from experiment compared well with that estimated from this formula, with the average ratio of the experimental/predicted data being close to unity and proposed to be used to estimate the STS of High Performance Concrete. The effect of coarse aggregate type (crushed quartzite, crushed granite, lime stone and marble) on the compressive strength, splitting tensile strength, fracture energy, characteristic length and elastic modulus of concrete produced with 28 days target compressive strengths of $30(\mathrm{~W} / \mathrm{B}=0.55), 60(\mathrm{~W} / \mathrm{B}=0.44)$ and $90 \mathrm{MPa}(\mathrm{W} / \mathrm{B}=0.26)$ was studied [23] and found that for all grades crushed quartzite coarse aggregates concrete showed higher compressive strength (44.8 $\mathrm{MPa}$, $70.4 \mathrm{MPa}, 98.2 \mathrm{MPa}$ ), higher split tensile strength (4.1 $\mathrm{MPa}, 5.2 \mathrm{MPa}, 8.4 \mathrm{MPa})$, higher fracture energy (143.1 $\mathrm{MPa}, 158.1 \mathrm{MPa}, 166.1 \mathrm{MPa})$, higher modulus of elasticity (37.5 GPa, 39.5 GPa, 48.2 GPa) and higher characteristic length $(0.319 \mathrm{~m}, 0.231 \mathrm{~m}, 0.113 \mathrm{~m})$. A High Performance Concrete has been successfully developed for a digitally-controlled printing process which can build architectural and structural components without formwork. The well printed concrete had significantly fewer voids, higher flexural strength [24]. B. K. Raghu Prasad et al. [25] proposed an artificial neural network (ANN) to predict 28 days compressive strength of high performance concrete. The high values of $\mathrm{R}^{2}$ demonstrated that the proposed ANN model was suitable for predicting the compressive strength values very closely with the experimental values. With extremely low W/B (0.14 - 0.18), high binder content, multi addition of SF, GGBS, lime stone powder and high standard superplasticizer Ultra High performance concrete can be prepared with common technology and without removing the coarse aggregate [26]. Compressive strength, Chloride Permiability and shrinkage cracking potential test results indicate that admixtures may enhance durability without increasing strength [27]. Grade 100 high performance Concrete $(\mathrm{W} / \mathrm{B}=0.223)$ was produced by using sulphate resisting 
cement and silica fume (10\%) with $1 \%$ superplasticizer for the marine environment. It showed high impermeability (stable current of circuit 2.7 - $3.5 \mathrm{~mA}$, destroyed time 41 days), high elastic modulus (6.5 MPa), high ability to steel adhesion (steel adhesion factor $=33.37$ ), high strength development (60 MPa) at 3 days [28]. A. Elahi et al. [29] carried out investigation to evaluate the mechanical and durability properties of High Performance Concrete $(\mathrm{W} / \mathrm{B}=0.3)$ containing supplementary cementitious materials (Silica Fume, Fly Ash, Ground Granulated Blast Furnace Slag) in binary and ternary systems. Portland cement was replaced with fly ash upto $40 \%$, silica fume upto $15 \%$ and GGBS upto a level of $70 \%$. The ternary mixes containing GGBS or Fly Ash $(50 \%)$ and Silica Fume (7.5\%) performed the best amongst all the mixes to resist the chloride diffusion. Silica fume (7.5\%) performs better than other supplementary cementitious materials for the strength development. There was a benefit in case of sorptivity with the addition of $20 \%$ FA and 50\% GGBS compared to control concrete. High Performance Concrete mixes containing fine ground ceramics as Portland cement replacement in an amount of upto $60 \%$ of mass were developed by Eva Vejmelkova et al. [30]. The compressive strength decreased very fast for the replacement levels higher than $20 \%$; the produced concrete lost its high performance character. For same level water absorption coefficient was relatively low, the frost resistance was excellent and showed good chemical resistance in $\mathrm{MgCl}_{2}, \mathrm{NH}_{4} \mathrm{Cl}, \mathrm{Na}_{2} \mathrm{SO}_{4}, \mathrm{HCl}$ environments. H. S. wong et al. [31] carried laboratory investigation to determine the cementing efficiency factor $\mathrm{k}$ of a pozzolan (number of parts of cement in a concrete mixture that could be replaced by one part of pozzolan) without changing the property. Investigation on silica fume (SF) and metakaoline (MK) concrete found that $\mathrm{k}$ varied with pozzolan type, replacement level and age. $\mathrm{K}$ increased with age but declined with high pozzolanic content. H. Z. Lopez-Calvo et al. [32] evaluated the influence of calcium nitrite based corrosion inhibitor (CNI) at addition rates of $0,12.5$ and $25 \mathrm{~L} / \mathrm{m}^{3}$ on the compressive strength of High Performance Concrete manufactured with $8 \%$ silica fume blended cement in combination with $0 \%$, $20 \%$ and $40 \%$ FA replacements and mixed at $0.29,0.37$ and $0.45 \mathrm{~W} / \mathrm{B}$ ratio. In concretes tested at 28 days and 1 year, when $12.5 \mathrm{~L} / \mathrm{m}^{3} \mathrm{CNI}$ was incorporated into the mixture, an increase in compressive strength of approximately $15 \%$ to $17 \%$ were observed for all the W/B ratio. In concrete specimens tested at 9 years, when 12.5 $\mathrm{L} / \mathrm{m}^{3} \mathrm{CNI}$ was added to a concrete mixture, an increase in compressive strength of $4 \%, 13 \%, 23 \%$ for $0.29,0.37$ and $0.45 \mathrm{~W} / \mathrm{B}$ was found. An experimental investigation was carried out by $\mathrm{Da} \mathrm{Xu}$ et al. [33] to develop High Performance Concrete with targeted strength $120 \mathrm{MPa}$. Two mixes of OPC concrete were cast, one with $10 \%$
Unidensified Silica fume (USF) replacement and other one with 10\% USF and 30\% Ultra Fine Ground Granulated Blast Furnace Slag (UFGGBS) replacement with $0.25 \mathrm{~W} / \mathrm{B}$ ratio. Both Mix showed High Compressive Strength at 28 days (as high as $135 \mathrm{MPa}$ ), a high flexural strength (nearly $12 \mathrm{MPa}$ ), Very high secant modulus of elasticity $(45.5 \mathrm{MPa})$, Electrical resistivity above 20 $\mathrm{k} \Omega-\mathrm{cm}$ result in a low corrosion rate for the embedded steel reinforcement. Khalifa S. Al Jabri et al. [34] investigated the effect of copper slag as a replacement of sand on the properties of high performance concrete $(\mathrm{W} / \mathrm{B}=$ 0.35 ). Eight concrete mixtures were prepared with different proportions of copper slag $(0 \%, 10 \%, 20 \%, 40 \%$, $50 \%, 60 \%, 80 \%$, and $100 \%$ ). Beyond $50 \%$ of copper slag as sand replacement caused reduction in strength and increase in water absorption rate. Results showed that $40 \%$ weight of copper slag can be used as replacement of sand in order to obtain High Performance Concrete with good properties. High Performance Concrete with a maximum compressive strength of $95.4 \mathrm{MPa}$ was produced using $10 \%$ metakaolin with $\mathrm{W} / \mathrm{B}$ ratio of 0.3 [35]. The Chloride Ion Permeability value decreased considerably with increase in metakaolin content from 0 to $30 \%$ thus indicating improved durability with increasing metakaolin content. Dr. H. Sudarsana Rao et al. [36] produced Glass fibre reinforced High Performance Concrete $(\mathrm{W} / \mathrm{B}=0.35)$ with Fly Ash $(0 \%, 10 \%, 20 \%, 30 \%)$ as the mineral admixture and glass fibre $(0 \%, 0.5 \%, 1 \%, 1.5 \%)$. Cubes and Cylinders were tested to assess compressive and tensile strength characteristics and also workability by conducting compaction factor test. Compaction factor workability of GFRHPC mixes was decreased with increase in percentage replacement of cement by fly ash for all percentages of glass fibre ratio. Maximum compressive strength and tensile strength was attained at $1 \%$ of glass fibre ratio with $10 \%$ fly ash. Sung Won Yoo et al. [37] evaluated autogenous shrinkage in HPC $(\mathrm{W} / \mathrm{B}=0.3)$ with mineral admixtures fly ash $(0 \%, 10 \%, 15 \%, 20 \%$, $30 \%)$ and silica fume $(0 \%, 5 \%, 7.5 \%, 10 \%, 15 \%) \&$ chemical admixture shrinkage reducing agent and expansion agent. The autogenous shrinkage (AGS) in High Performance Concrete with fly ash was decreased continuously with larger fly ash replacement. AGS in High Performance Concrete with silica fume was increased compared to that in OPC concrete. Use of both admixtures in adequate amount can provide decrease in AGS as well as improvement of the strength. J. Brozovsky et al. [38] indicated calibration correlations as elaborated for high performance concrete class C55/67 to C80/95; 2 to 60 days old, for Schmidt impact hammer type N\&L. They are compared with relations specified in the norms EN13791 and CSN731373, and concluded that they are applicable to practical detection of built in high performance concrete strength. Noumowe et al. [39] carried 
out experimental investigations to study the effect of elevated temperature $\left(600^{\circ} \mathrm{C}\right)$ on permeability of control high performance concrete, high performance concrete incorporating polypropylene fibres and high performance concrete made with lightweight aggregates. The W/B ratio was kept 0.3 and silica fume was used $10 \%$ by weight of cement as replacement. A heating-cooling cycle was applied on cylindrical specimens; $65 \mathrm{~mm}$ thick slices were cut from each cylinder and dried prior to being subjected to permeability test (before and after the heating cooling cycle). There was severe loss in the permeability of High Performance Concrete with normal aggregates. The permeability of the fibre reinforced high performance concrete was greater than that of the control high performance concrete. Investigations were carried out by K. M. A. Hossain et al. [40] to assess the suitability of using volcanic ash (VA) as a cement replacement material to produce High Performance Concrete having constant $\mathrm{W} / \mathrm{B}$ ratio of 0.3 . HPVACs having a 28 -day compressive strength in excess of $60 \mathrm{MPa}$ can be achieved by using upto $20 \%$ VA. The drying shrinkage of HPVACs was slightly higher compared to control concrete $(0 \% \mathrm{VA})$. All HPVACs showed rapid chloride permeability (RCP) values within the range of $100-1000$ Coulomb which suggests that they have very low permeability as per ASTM C 1202 - 97. There was no obvious increase in the width of the Interfacial transition zone in HPVACs compared to control concrete. Three point bend tests for High Performance Concrete notched beams were performed to determine the fracture parameters by Ricardo A. Einsfeld et al. [41]. The results obtained by the work of fracture method apparently follow the trend of fracture energy increasing as the compressive strength of the concrete increases. The results for fracture energy obtained by the size effect method showed a slight trend to decrease with increasing compressive strength. Compressive strength, gas permeability and carbonation of High Performance Concrete (W/B ratio $0.25,0.30$ and $0.35)$ with fly ash $(15 \%, 30 \%, 45 \%$, and $60 \%)$ or ground granulated blast furnace slag $(15 \%, 30 \%, 45 \%, 60 \%)$ were experimentally investigated by Shi Hui Sheng et al. [42]. At lower W/B ratio, compared to control High Performance Concrete, FA with replacement upto 30\% improved compressive strength, and had marginal increase in both gas permeability and carbonation depth. High Performance Concrete with GGBS showed better performance and properties were little affected by W/B ratio. The compressive strength of silica fume $(10 \%, 20 \%$, and $30 \%$ ) concretes was investigated by E. H. Kadri et al. [43] at lower water binder $(0.25,0.30,0.35$, and 0.45$)$ with a naphthalene sulphonate superplasticizer. The results showed that partial cement replacement upto $20 \%$ had produced higher compressive strengths than control concretes for all W/B ratios. An experimental investigation on the flexural behaviour of reinforced high performance concrete was conducted by Paramsivam suresh kumar et al. [47] by using crushed sand stone as fine and coarse aggregates in addition with silica fume and fly ash combined with superplasticizer. The beams were made with concrete having compressive strength in the range of 74 $88 \mathrm{~N} / \mathrm{mm}^{2}$ and tensile reinforcement in the range of $1.34 \%$ to $3.14 \%$. The ultimate experimental moment was found to be $3 \%$ - $15 \%$ higher than predicted ultimate moment by ACI 318, actual deflections of the beams were found slightly above allowable values under service loads \& observed crack widths under service loads were within acceptable limits. Effect of kerosene and Gasoline on some properties of high performance concrete $(\mathrm{W} / \mathrm{B}=$ 0.31 ) which can be used as storage tanks for petroleum products was checked by performing experimental work. Specimen exposed to Kerosene and Gasoline showed more weight loss and reduction in compressive strength at 7, 28 and 90 days [48]. By using fractional factorial design concept, Salilkumar roy et al. [49] prepared sixteen mixes from a basic mix (cement:sand:aggregates:fly ash $=1: 1.3: 2.6: 0.8$ with $\mathrm{W} / \mathrm{C}=0.37)$ and determined changes $($ cement $=0.1$; sand $=0.1$; aggregates $=0.2$; fly ash $=0.4$ and changing water cement ratio by 0.01 ) using Taguchi's orthogonal array. The changed composition mix was found to have highest compressive strength and lowest water absorption and therefore found to be best for making paving blocks. Flexural and Spliting tensile strengths of high performance fiber reinforced concrete were determined with variables fiber volume fraction $(0 \%, 0.5 \%, 1 \%, 1.5 \%$ with an aspect of 80$)$, silica fume replacement level $(0 \%, 10 \%, 20 \%, 30 \%)$ and $\mathrm{W} / \mathrm{B}$ ratio $=$ 0.35 . The addition of steel fibers upto $1.5 \%$ resulted in increase of $38 \%$ in the flexural tensile strength, and an increase of $56 \%$ in the splitting tensile strength compared with a plain concrete matrix [50]. K. Arunachalam et al. [51] performed experiments to make a comparative study on the properties of high performance concrete $(\mathrm{W} / \mathrm{B}=$ $0.28)$ with fly ash (25\% and $50 \%$ replacement) and without fly ash (control concrete) in normal and aggressive environment $\left(\mathrm{Al}_{2} \mathrm{SO}_{4}\right.$ and $\left.\mathrm{NaCl}\right)$. In case of control concrete under aggressive environment compressive strength was decreased from 28 to 60 days by about $25 \%$ of 28 days strength. There was a continuous increase in compressive strength from 7 days to 60 days for high performance fly ash concrete (both $25 \%$ and $50 \%$ cement replacement) for both environment. Five categories of High Performance Concrete namely Normal Strength Concrete (35 MPa), Medium Strength Concrete (56 $\mathrm{MPa})$, High Strength Concrete (62 $\mathrm{MPa})$, Very High Strength Concrete (98 MPa), Ultra High Strength Concrete $(120 \mathrm{MPa})$ with slump value ranged from (100 $200 \mathrm{~mm}$ ) were designed by Mohamed M Yoursy El shikh [52] with the help of commercial software taking into 
account the Egyptian practice and assigned that to different column cases (edge, corner and internal) for high rise residential building (12 stories with $3 \mathrm{~m}$ height of each storey). The columns are analysed and designed which showed that total cost reduction of all columns vary from $(32 \%$ to $57 \%)$ corresponding to concrete strength (56 to $100 \mathrm{MPa}$ ) compared with Normal Strength Concrete (35 MPa). Vaishali G Ghorpade [53] performed tests on four mixes of concrete with $0 \%, 0.5 \%, 1.0 \%$ and $1.5 \%$ by volume fraction of glass fiber, silica fume $(0 \%$, $10 \%, 20 \%, 30 \%$ by weight of cement) with $\mathrm{W} / \mathrm{B}$ ratio $=$ 0.35 , aggregate/binder $=2.0$ and superplasticizer $1 \%$ of the weight of cement. The optimum percentage recommended as $1 \%$ fibre volume with $10 \%$ silica fume for achieving maximum benefits in compressive strength, split tensile strength and flexural strength. Experimental investigations were carried out by Saeed ahmed al. Sheikh [54] on High Performance Concrete $(\mathrm{W} / \mathrm{B}=0.35)$ by heating them in an electric furnace to varying temperatures upto $1000^{\circ} \mathrm{C}$ and the change in compressive strength, tensile strength, ultrasonic pulse velocity and rebound hammer were determined. High Performance Concrete showed reduction in compressive and tensile strengths about $69 \%$ and $73 \%$ respectively. Pulse Velocity and rebound hammer of High Performance Concrete were also decreased by $76 \%$ and $21 \%$ respectively. Quantitative assessment of different cement replacement levels with silica fume $(0 \%, 2.5 \%, 5 \%, 7.5 \%, 10 \%$, $12.5 \%, 15 \%)$ on strength and durability properties for $\mathrm{M} 60(\mathrm{~W} / \mathrm{B}=0.32), \mathrm{M}_{70}(\mathrm{~W} / \mathrm{B}=0.3)$ and $\mathrm{M} 110(\mathrm{~W} / \mathrm{B}=$ 0.232) grades of High Performance Concrete mixes was carried out by K. Perumal et al. [55]. Replacement level of $10 \%$ with silica fume in $\mathrm{M}_{60}, \mathrm{M}_{70}$, and $\mathrm{M}_{110}$ grades of High Performance Concrete mixes was found to be the optimum level to obtain higher values of compressive strength (72.22 MPa, 82.46 MPa, 121.22 MPa), split tensile strength (6.10 $\mathrm{MPa}, 5.85 \mathrm{MPa}, 8.45 \mathrm{MPa})$, flexural strength (8.3 MPa, 9.1 $\mathrm{MPa}, 8.45 \mathrm{MPa})$ and elastic modulus (35.1 GPa, 37.5 GPa, $44.4 \mathrm{GPa}) \&$ lower values of porosity $(2.2 \%, 2.15 \%, 1.95 \%)$, sorptivity $(0.0210$ $\mathrm{mm} / \mathrm{min}^{0.5}, 0.0205 \mathrm{~mm} / \mathrm{min}^{0.5}, 0.0104 \mathrm{~mm} / \mathrm{min}^{0.5}$ ) and saturated water absorption $(1.25 \%, 1.2 \%, 1.05 \%)$. Compressive Strength and Modulus of Elasticity of High Performance Concrete made with silica fume, ground granulated blast furnace slag, fly ash and normal Portland cement with $\mathrm{W} / \mathrm{B}=0.25$ and exposed to temperature within the range of $20^{\circ} \mathrm{C}$ to $50^{\circ} \mathrm{C}$ under different types of curing methods were determined [56]. The highest levels of strength and modulus of elasticity were obtained by silica fume concrete under water and wrapped curing at temperature of $35^{\circ} \mathrm{C}$. High Performance Concrete was produced by Andres Salas et al. [57] by using Rice Husk Ash samples (conventional type TRHA obtained by a thermal treatment and other chRHA was based on a chemical thermal attack to the rice husk ash). Compressive and Flexural Strengths of chRHA concrete were comparable to a silica fume concrete made with the same replacement level \& these strengths were higher than the control and TRHA mixtures. Through the optimization of the proportions of compositions and employing heat treatment, very high performance concrete with large quantities of ultrafine mineral powders such as pulverized fly ash, pulverized granulated blast furnace slag and silica fume was successfully prepared which showed compressive strength upto $200 \mathrm{MPa}$ [58]. High Performance concrete utilizing fly ash and microsilica as cement replacing materials was investigated [59] to study permeation related properties like permeability, porosity and sorptivity with different curing conditions namely moist curing, air curing and curing at $5^{\circ} \mathrm{C}$. The permeability, porosity and sorptivity values were lowest for low W/B ratio with $10 \%$ microsilica and fly ash replacement in the range of $15 \%-20 \%$. Same permeability values were not achieved for specimens cured at $5^{\circ} \mathrm{C}$ in comparison with moist and air curing. The research was conducted [60] to obtain the optimum High Performance Concrete (W/B = 0.35 ) mix by using $10 \%$ silica fume and various percentages of pulvarized fly ash $(40 \%, 60 \%, 80 \%)$ with melamine superplasticizer. The resistance of the produced concrete when exposed to an acidic environment $\left(\mathrm{H}_{2} \mathrm{SO}_{4}, \mathrm{HCl}\right)$ was reduced in mix with $10 \%$ silica fume and fly ash more than $60 \%$ as an OPC replacement. Compressive strength of High Performance Concrete and Paste mixes was found by K. O. kjellsen et al. [61] at ages 1 day to 4 years with $\mathrm{W} / \mathrm{B}$ ratio ranged from 0.25 to 0.4 and upto $10 \%$ of the cement was replaced by silica fume. The concretes and the pastes with $10 \%$ silica fume appeared to reduce strength between 3 and 9 months and were higher at 2 years than after 3 months. The direct tensile strength, flexural strength, compressive strength, dynamic modulus of elasticity and fracture energy of High Performance Concrete mixes (W/B $=0.25 \& 0.4$ ) and silica fume $(0 \%, 10 \%)$ at 28 days and 2 years were studied by K. O. Kjellsen et al. [62]. An increase of $20 \%$ to $25 \%$ in direct tensile strength and $10 \%$ to $25 \%$ in flexural \& compressive strength with little effect on the dynamic modulus of elasticity was found with $10 \%$ silica fume. A method to find coefficient of thermal expansion of High Performance Concrete was proposed by H. Kada et al. [63] in which concrete samples instrumented with vibrating wire extensometer were given thermal shocks $\&$ measured deformation and temperature signal were used to calculate coefficient of thermal expansion. High Performance Concrete with $0 \%, 5 \%, 10 \%$ and $20 \%$ metakaolin at $\mathrm{W} / \mathrm{B}$ ratio of 0.3 was prepared by $\mathrm{C}$. S. Poon et al. [64] to investigate compressive strength, porosity and pore size distribution and compared with concrete made by $5 \%$ and $10 \%$ silica fume as replacement of cement $\&$ 
cured in water at $27^{\circ} \mathrm{C}$ for 3 days to 90 days. Metakaolin replaced concrete showed higher compressive strength at all days compared to silica fumed concrete. Porosity and pore diameter was decreased for all concrete as curing age increased. A High Performance $\mathrm{C}_{40}$ grade non dispersible underwater concrete was manufactured with the use of Non dispersible admixture by Jiang Cong-Sheng et al. [65] which showed low flow loss, low strength loss and excellent anti dispersion in comparison with control conctere. PAN Zhihua et al. [66] developed high performance foamed concrete using blast furnace slag, fly ash and silica fume as cement replacement by means of pre foaming process with different mix proportions of mineral admixtures which showed compressive strength $1.1-23.7 \mathrm{MPa}$ and thermal conductivity of about 0.16 $0.75 \mathrm{~W} / \mathrm{m}^{\circ} \mathrm{C}$. It was observed that with small amount of superplasticizer the compressive strength reached as high as 44.1 MPa. Lu Jianfu et al. [67] examined compressive strength \& chloride penetration resistance of high performance concrete under three curing conditions namely SC (standard curing), MC (Matched curing, sealed specimens with plastic membrane in temperature controlled curing box) and MNC (Matched curing of naked concrete, naked specimens in temperature controlled curing box). The concrete under MC and MNC showed better resistance to chloride penetration than one under $\mathrm{SC}$ and compressive strength of SC concrete was higher at 248 days. Corrosion Reinforced high performance concrete was studied by Pedro Montes et al. [68] by using fly ash and calcium nitrite corrosion inhibitor. The combination of good quality concrete $(\mathrm{W} / \mathrm{C}=0.29)$ with Calcium Nitrite Corrosion Inhibitor at an addition rate of $12.5 \mathrm{~L} / \mathrm{m}^{3}$ was found best to reduce the effect of Chloride induced corrosion of steel reinforcement. Hardened properties of the high performance concrete containing high replacement level of slag $(50 \%-80 \%)$ under air and wet curing regimes were studied by Erhan Guneyisi et al. [69]. With increase in slag content, corrosion resistance was increased, compressive strength, splitting tensile strength and water absorption were decreased. Rice husk Ash with high carbon High Performance Concrete [70] showed superior performance in the mechanical and durability tests compared with the reference mix. The mixing time of the High Performance Concrete [71] can be reduced by increasing the relative solid concentration (by optimising the particle size distribution, replacement of cement by silica fume), matching the type of superplasticizer and cement in the mix and increasing the speed of mixing. A HPC made with different $\mathrm{W} / \mathrm{C}$ ratios $(0.30$, $0.40)$ and light weight sand ( $0 \%$ and $30 \%$ by volume) as sand substitution by Soo Duck Hwang [72] was used to check the effect of moist curing. Combined use of $30 \%$ light weight sand and 7 days of moist curing can lead to greater increase in compressive strength and larger de- crease in total shrinkage compared to the use of $30 \%$ light weight sand without moist curing or 7 days of moist curing without light weight sand. K.chinnaraju et al. [74] conducted an Experimental test programme to study the effect of fly ash, GGBS and silica fume on High Performance Concrete with $\mathrm{W} / \mathrm{B}$ ratio 0.32 . The control concrete mixture of grade M60 included only ordinary Portland cement as binder and other mixtures incorporated binary $(\mathrm{PC}+$ flyash, $\mathrm{PC}+\mathrm{GGBS}, \mathrm{C}+\mathrm{SF})$, ternary $(\mathrm{PC}+$ flyash + GGBS, C + flyash $+\mathrm{SF}, \mathrm{PC}+\mathrm{GGBS}+$ $\mathrm{SF})$ and quaternary $(\mathrm{PC}+$ flyash + GGBS $+\mathrm{SF})$ cementitious blends were designed. The replacement levels for both flyash and GGBS were $10 \%, 20 \%$ and $30 \%$, while those of SF were $2.5 \%, 7.5 \%, 10 \%$ and $12.5 \%$ by weight of cement as addition. The mix with $20 \%$ replacement of cement by $10 \%$ of fly ash and $10 \%$ of silica fume showed the best compressive strength for 7 days and 28 days, with an increase in compressive strength of $15.64 \%$ and $13.24 \%$ respectively. The increase in splitting tensile strength was moderate for various combinations of fly ash and GGBS with silica fume upto $10 \%$. Beyond that there was no increase in splitting tensile strength. The change in flexural strength was limited for most of the combinations but was decreased with higher rate beyond the addition of $10 \%$ silica fume. Several researchers designed High Performance Concrete mixes by using mix design methods of Normal Strength Concrete or by combining principles of one or more methods. However, suitability of existing mix design methods such as Indian Standard Code, Department of Environment, American Concrete Institute etc. for designing High Performance Concrete mixes giving necessary modifications had not been reported so far. From the experimental trials it was observed that all the methods of mix design did not give desired workability and compressive strength and needed some modifications for making High Performance Concrete mixes. Kumbhar et al. [44] suggested following modifications for existing mix design methods to achieve High Performance Concretes.

- Indian Standard code method gives lesser proportion of fine aggregates so a proper coarse to fine aggregate ratio should be recommended for better workability of mix. Further, Indian Standard code method incorporates use of only one mineral admixture. There should be modification in method in terms of addition of more than one mineral admixture with appropriate proportion of chemical admixture.

- Department of Environment method suggests higher quantity of fine aggregate which increases water required and hence reduces the strength which is not acceptable for High Performance Concrete. Therefore proper dosage of Superplasticizer should be recommended.

- Modified American Concrete Institute method gives 
usage of High dosage of Superplasticizer to get high slump which reduces the strength therefore proper content of SP should be recommended.

A mix design procedure for High Performance Concrete had been suggested by aminul Islam Laskar [45] which took rheological parameters into account to determine compressive strength, water cement ratio and aggregate volume to paste volume ratio. Instead of using water cement ratio and compressive strength relationship, relationship between compressive strength, paste volume-aggregate volume ratio; physical properties of aggregate and rheological parameters were used in mix design. Correlation charts for rheological parameters and compressive strength was developed based on cube test results of several trial mixes whose rheological parameters had also been found by the rheometer. Muhammad Fauzi Mohd.Zain et al. [46] developed prototype expert system called HPCMIX according to the mix design method proposed by Aitcin that gave proportion of trial mix of High Performance Concrete and recommendations on mix adjustment. Mehta and Aitcin [73] proposed a simplified mixture proportioning procedure that was applicable for normal weight concrete with compressive strength values between 60 and $120 \mathrm{MPa}$. This method was suitable for coarse aggregates having a maximum size of between $10 \mathrm{~mm}$ and $15 \mathrm{~mm}$ and slump values of between 200 and $250 \mathrm{~mm}$. The optimum volume of aggregate was suggested to be $65 \%$ of the volume of the high performance concrete.

\section{Conclusions}

1) High Performance Concrete can be prepared to give optimized performance characteristics for a given loading and exposure conditions along with the requirements of cost, service life and durability.

2) The applications of concrete will necessitate the use of High Performance Concrete incorporating new generation chemical admixtures (PCE based superplasticizers) and available mineral admixtures.

3) The success of High Performance Concrete requires more attention on proper Mix Design, Production, Placing and Curing of Concrete. For each of these operations controlling parameters should be achieved by concrete producer for an environment that a structure has to face.

\section{REFERENCES}

[1] A. Kmita, "A New Generation of Concrete in Civil Engineering," Journal of Materials Processing Technology, Vol. 106, No. 1-3, 2000, pp.80-86. doi:10.1016/S0924-0136(00)00642-7

[2] M. J. Shannag and H. A. Shaia, "Sulfate Resistance of High-Performance Concrete", Cement \& Concrete Composites, Vol. 25, No. 3, 2003, pp. 363-369.
doi:10.1016/S0958-9465(02)00049-5

[3] N. V. Ramana, K. Gnaneswar, C. Sashidhar and T. Naresh Kumar, "Behavior of High Performance Concrete Two Way Slabs in Punching Shear", International Journal of Science and Advanced Technology, Vol. 2, No. 3, 2012, pp. 122-126.

[4] P. Muthupriya, K. Subramanian and B. G. Vishnuram, "Experimental Investigation on High Performance Reinforced Concrete Column with Silica Fume and Fly Ash as Admixtures", Asian Journal of Civil Engineering (Building and Housing), Vol. 12, No. 5, 2011, pp. 597-618.

[5] S. A. Al-Mishhadani, W. A. Al-Qaisi and S. F. Al-Khafaji, "Predicting Mechanical Properties of High Performance Concrete by Using Non-Destructive Tests," Journal of Engineering \& Technology, Vol. 27, No. 3, 2009, pp. 425-444.

[6] B. B. Patil and P. D. Kumbhar, "Strength and Durability Properties of High Performance Concrete Incorporating High Reactivity Metakaolin," International Journal of Modern Engineering Research, Vol. 2, No. 3, 2012, pp. 1099-1104.

[7] V. G. Ghorpade and H. S. Rao, "Chloride Ion Permeability Studies of Metakaolin Based High Performance Concrete," International Journal of Engineering Science and Technology, Vol. 3, No. 2, 2011, pp. 1617-1623.

[8] S. Bhanja and B. Sengupta, "Influence of Silica Fume on the Tensile Strength of Concrete," Cement and Concrete Research, Vol. 35, No. 4, 2005, pp. 743-747.

doi:10.1016/j.cemconres.2004.05.024

[9] K. Yildiz and L. O. Ugur, "Examination of Durablity of High Performance Concrete (hpc) That Has Been Subjected to $\mathrm{MgSO}_{4}$ and $\mathrm{NaCl}$ Corrosion against Freezing and Thawing," Scientific Research and Essay, Vol. 4, No. 9, 2009, pp. 929-935.

[10] A. I. Laskar and S. Talukdar, "Rheological Behavior of High Performance Concrete with Mineral Admixtures and Their Blending," Construction and Building Materials, Vol. 22, No. 12, 2008, pp. 2345-2354. doi:10.1016/j.conbuildmat.2007.10.004

[11] A. H. Memon, S. S. Radin, M. F. M. Zain and J. F. Trottier, "Effects of Mineral and Chemical Admixtures on High-Strength Concrete in Seawater," Cement and Concrete Research, Vol. 32, No. 3, 2002, pp. 373-377. doi:10.1016/S0008-8846(01)00687-1

[12] I. R. F. Martins and J. L. Akasaki, "Study of Compressive Strength of High Performance Concrete Added with Tire Rubber", Materials Compuestos, 2005, pp. 1-8.

[13] V. Malagavelli and P. N. Rao, "High Performance Concrete with Ggbs and Robo Sand," International Journal of Engineering Science and Technology, Vol. 2, No. 10, 2010, pp. 5107-5113.

[14] K. Pazhani and R. Jeyaraj, "Study on Durability of High Performance Concrete with Industrial Wastes," Applied Technologies \& Innovations, Vol. 2, No. 2, 2011, pp. 1928.

[15] J. A. Peter, M. Neelamegam, J. K. Dattatreya, N. P. Rajamane and S. Gopalkrishnan, "Utilisation of Flyash as Cement Replacement Material to Produce High Perfor- 
mance Concrete", In: B. Cltatterjee, K. K. Singh \& N. G. Goswami, Eds., Fly Ash Utilisation for Value Added Products, 1999, pp. 38-49.

[16] A. Camoes, B. Aguiar and S. Jalali, "Durability of Low Cost High Performance Fly Ash Concrete," International Ash Utilization Symposium, Center for Applied Energy Research, University of Kentucky, Paper 43, 2003.

[17] H. H. Nassif , H. Najm and N. Suksawang, "Effect of Pozzolanic Materials and Curing Methods on the Elastic Modulus of HPC," Cement \& Concrete Composites, Vol. 27, No. 6, 2005, pp. 661-670. doi:10.1016/j.cemconcomp.2004.12.005

[18] E. Vejmelkova, M. Keppert, P. Rovnanikova, M. Ondracek, Z. Kersner and R. Cerny, "Properties of High Performance Concrete Containing Fine-Ground Ceramics as Supplementary Cementitious Material," Cement \& Concrete Composites, Vol. 34, No. 1, 2012, pp. 55-61. doi:10.1016/j.cemconcomp.2011.09.018

[19] K. E. Hassan, J. G. Cabrera and R. S. Maliehe, "The Effect of Mineral Admixtures on the Properties of High Performance Concrete," Cement \& Concrete Composites, Vol. 22, No. 4, 2000, pp. 267-271. doi:10.1016/S0958-9465(00)00031-7

[20] G. Li and X. Zhao, "Properties of Concrete Incorporating Fly Ash and Ground Granulated Blast-Furnace Slag," Cement \& Concrete Composites, Vol. 25, No. 3, 2003, pp. 293-299. doi:10.1016/S0958-9465(02)00058-6

[21] A. Shukla, C. K. Singh and A. Sharma, "Study of the Properties of Concrete by Partial Replacement of Ordinary Portland Cement by Rice Husk Ash," International Journal of Earth Sciences and Engineering, Vol. 4, No. 6, 2011, pp. 965-968.

[22] M. F. M. Zain, H. B. Mahmud, A. Ilham and M. Faizal, "Prediction of Splitting Tensile Strength of High-Performance Concrete," Cement and Concrete Research, Vol. 32, No. 8, 2002, pp. 1251-1258. doi:10.1016/S0008-8846(02)00768-8

[23] K. Wu, B. Chen, W. Yao and D. Zhang, "Effect of Coarse Aggregate Type on Mechanical Properties of High-Performance Concrete," Cement and Concrete Research, Vol. 31, No. 10, 2001, pp. 1421-1425. doi:10.1016/S0008-8846(01)00588-9

[24] T. T. Le, S. A. Austin, S. Lim, R. A. Buswell, R. Law, A. G. F. Gibb and T. Thorpe, "Hardened Properties of HighPerformance Printing Concrete," Cement and Concrete Research, Vol. 42, No. 3, 2012, pp. 558-566. doi:10.1016/j.cemconres.2011.12.003

[25] B. K. Raghu Prasad, H. Eskandari and B. V. Venkatarama Reddy, "Prediction of Compressive Strength of SCC and HPC with High Volume Fly Ash Using ANN," Construction and Building Materials, Vol. 23, No. 1, 2009, pp. 117-128. doi:10.1016/j.conbuildmat.2008.01.014

[26] C. Wang, C. Yang, F. Liu, C. Wan and X. Pu, "Preparation of Ultra-High Performance Concrete with Common Technology and Materials," Cement \& Concrete Composites, Vol. 34, No. 4, 2012, pp. 538-544. doi:10.1016/j.cemconcomp.2011.11.005

[27] S. P. Shah and W. J. Weiss, "High Performance Concrete: Strength, Permeability and Shrinkage Cracking," Interna- tional Symposium on High Performance Concrete, 2000, pp. 331-340.

[28] P. H. Hanh and N. V. Tuan, "High Performance Concrete Used for Marine Gravity Concrete Works," The 3rd ACF International Conference, 2008, pp. 598-606.

[29] A. Elahi, P. A. M. Basheer, S. V. Nanukuttan and Q. U. Z. Khan, "Mechanical and Durability Properties of High Performance Concretes Containing Supplementary Cementitious Materials," Construction and Building Materials, Vol. 24, No. 3, 2010, pp. 292-299.

doi:10.1016/j.conbuildmat.2009.08.045

[30] E. Vejmelkova, M. Keppert, P. Rovnanikova, M. Ondracek, Z. Kersner and R. Cerny, "Properties of High Performance Concrete Containing Fine Ground Ceramics as Supplementary Cementitious Material," Cement \& Concrete Composites, Vol. 34, No. 1, 2012, pp. 55-61. doi:10.1016/i.cemconcomp.2011.09.018

[31] H. S. Wong and H. A. Razak, "Efficiency of Calcined Kaolin and Silica Fume as Cement Replacement Material for Strength Performance," Cement and Concrete Research, Vol. 35, No. 4, 2005, pp. 696-702. doi:10.1016/j.cemconres.2004.05.051

[32] H. Z. Lopez-Calvo, P. Montes-Garcia, T. W. Bremner, M. D. A. Thomas and V. G. Jiménez-Quero, "Compressive Strength of HPC Containing CNI and Fly Ash after Long-Term Exposure to a Marine Environment," Cement \& Concrete Composites, Vol. 34, No. 1, 2012, pp. 110118. doi:10.1016/j.cemconcomp.2011.08.007

[33] D. Xu, B. S. Divsholi, D. T. Y. Lim and S. Teng, "Mechanical Properties and Durability of High Performance Concrete Incorporating Ultra Fine Slag and Undensified Silica Fume," 36th Conference on Our World in Concrete \& Structures Singapore, 14-16 August 2011, pp. 1-10.

[34] K. S. Al-Jabri, M. Hisada, S. K. Al-Oraimi and A. H. Al-Saidy, "Copper Slag as Sand Replacement for High Performance Concrete," Cement \& Concrete Composites, Vol. 31, No. 7, 2009, pp. 483-488. doi:10.1016/j.cemconcomp.2009.04.007

[35] V. G. Ghorpade and H. S. Rao, "Chloride Ion Permeability Studies of Metakaolin Based High Performance Concrete," International Journal of Engineering Science and Technology, Vol. 3, No. 2, 2011, pp. 1617-1623.

[36] H. S. Rao, H. M. Somasekharaiah and V. G. Ghorpade, "Strength and Workability Characteristics of Fly Ash Based Glass Fibre Reinforced High Performance Concrete," International Journal of Engineering Science and Technology, Vol. 3, No. 8, 2011, pp. 6266-6277.

[37] S. W. Yoo, S. J. Kwon and S. H. Jung, "Analysis Technique for Autogenous Shrinkage in High Performance Concrete with Mineral and Chemical Admixtures," Construction and Building Materials, Vol. 34, 2012, pp. 1-10. doi:10.1016/j.conbuildmat.2012.02.005

[38] J. Brozovsky, D. Prochazka and D. Benes, "Determination of High Performance Concrete Strength by Means of Impact Hammer," The 10th International Conference of the Slovenian Society for Non-Destructive Testing, Ljubljana, 1-3 September, 2009, pp. 233-241.

[39] A. N. Noumowe, R. Siddique and G. Debicki, "Permeability of High-Performance Concrete Subjected to Ele- 
vated Temperature $\left(600^{\circ} \mathrm{C}\right)$," Construction and Building Materials, Vol. 23, No. 5, 2009, pp. 1855-1861. doi:10.1016/j.conbuildmat.2008.09.023

[40] K. M. A. Hossain and M. Lachemi, "Strength, Durability and Micro-Structural Aspects of High Performance Volcanic Ash Concrete," Cement and Concrete Research, Vol. 37, No. 5, 2007, pp. 759-766. doi:10.1016/j.cemconres.2007.02.014

[41] R. A. Einsfeld and M. S. L. Velasco, "Fracture Parameters for High-Performance Concrete," Cement and Concrete Research, Vol. 36, No. 3, 2006, pp. 576-583. doi:10.1016/j.cemconres.2005.09.004

[42] H.-S. Shi, B.-W. Xu and X.-C. Zhou, "Influence of Mineral Admixtures on Compressive Strength, Gas Permeability and Carbonation of High Performance Concrete," Construction and Building Materials, Vol. 23, No. 5, 2009, pp. 1980-1985. doi:10.1016/j.conbuildmat.2008.08.021

[43] E. H. Kadri, S. Aggoun, S. Kenai and A. Kaci, "The Compressive Strength of High-Performance Concrete and Ultrahigh-Performance," Advances in Materials Science and Engineering, Vol. 2012, 2012, Article ID: 361857. doi: $10.1155 / 2012 / 361857$

[44] P. D. Kumbhar and P. B. Murnal, "Assessment of Suitability of Existing Mix Design Methods of Normal Concrete for Designing High Performance Concrete Mixes," International Journal of Civil and Structural Engineering , Vol. 3, No. 1, 2012, pp. 158-167.

[45] A. Laskar, "Mix Design of High-Performance Concrete," Materials Research, Vol. 14, No. 4, 2011, pp. 429-433. doi:10.1590/S1516-14392011005000088

[46] M. F. M. Zain, M. N. Islam and I. H. Basri, "An Expert System for Mix Design of High Performance Concrete," Advances in Engineering Software, Vol. 36, No. 5, 2005, pp. 325-337. doi:10.1016/j.advengsoft.2004.10.008

[47] P. S. Kumar, M. A. Mannan and K. V. John, "High Performance Reinforced Concrete Beams made with Sandstone Reactive Aggregates," The Open Civil Engineering Journal, Vol. 36, No. 5, 2008, pp. 41-50.

[48] N. Mahde, A. Jalawi and D. S. Atwan, "Effect of Kerosene and Gasoline on Some Properties of High Performance Concrete," Journal of Engineering, Vol. 17, No. 6, 2011, pp. 1643-1657.

[49] S. K. Roy, H. Sugiharto, A. Kristanto and S. Himawan, "Systematic Formulation of High Performance Concrete Pavement," Civil Engineering Dimension, Vol. 7, No. 2, 2005, pp. 57-60.

[50] P. Ramadoss and K. Nagamani, "Tensile Strength and Durability Characteristics of High Performance Fiber Reinforced Concrete," The Arabian Journal for Science and Engineering, Vol. 33, No. 2, 2008, pp. 307-319.

[51] K. Arunachalam and R. Gopalakrishnan, "Experimental Investigation on High Performance Fly Ash Concrete in Normal and Aggressive Environment," 29th Conference on Our World in Concrete \& Structures, Singapore City, 25-26 August 2004, pp. 181-188.

[52] M. M Y. El Shikh, "Economy of Using High Performance Concrete in Columns," 33rd Conference on Our
World in Concrete \& Structures, Singapore, 25-27 August 2008, pp. 1-8.

[53] V. G. Ghorpade, "An Experimental Investigation on Glass Fibre reinforced High Performance Concrete with Silicafume as Admixture," 35th Conference on Our World in Concrete \& Structures, Singapore, 25-27 August 2010, pp. 1-8.

[54] S. A. Al. Sheikh, "Mechanical Properties for High Performance Concrete Exposed to High Temperature," International Journal of Civil and Structural Engineering, Vol. 2, No. 2, 2011, pp. 534-444.

[55] K. Perumal and R. Sundararajan, "Effect of Partial Replacement of Cement with Silica Fume on the Strength and Durability Characteristics of High Performance Concrete," 29th Conference on Our World in Concrete \& Structures, Singapore, 25-26 August 2004, pp. 397-404.

[56] M. F. Mohd Zain and S. S. Radin, "Physical Properties of High-Performance Concrete with Admixtures Exposed to a Medium Temperature Range $20^{\circ} \mathrm{C}$ to $50^{\circ} \mathrm{C}$," Cement and Concrete Research, Vol. 30, No. 8, 2000, pp. 12831287. doi:10.1016/S0008-8846(00)00294-5

[57] A. Salas, S. Delvasto, R. Mejia de Gutierrez and D. Lange, "Comparison of Two Processes for Treating Rice Husk Ash for Use in High Performance Concrete," Cement and Concrete Research, Vol. 39, No. 9, 2009, pp. 773-778. doi:10.1016/j.cemconres.2009.05.006

[58] G. Long, X. Wang and Y. Xie, "Very-High-Performance Concrete with Ultrafine Powders," Cement and Concrete Research, Vol. 32, No. 4, 2002, pp. 601-605. doi:10.1016/S0008-8846(01)00732-3

[59] M. I. Khan, "Permeation of High Performance Concrete," Journal of Materials in Civil Engineering, Vol. 15, No. 1, 2003, pp. 84-92. doi:10.1061/(ASCE)0899-1561(2003)15:1(84)

[60] A. K. Tamini, "High Performance Concrete Mix for an Optimum Protection in Acidic Conditions," Materials and Structures, Vol. 30, No. 3, 1997, pp. 188-191. doi:10.1007/BF02486392

[61] K. O. Kjellsen, O. H. Wallevik and M. Hallgren, "On the Compressive Strength Development of High Performance Concrete and Paste Effect of Silica Fume," Materials and Structures, Vol. 32, No. 1, 1999, pp. 63-69. doi:10.1007/BF02480414

[62] K. O. Kjellsen, M. Hallgren and O. H. Wallevik, "Fracture Mechanical Properties of High Performance Concrete-Influence of Silica Fume," Materials and Structures, Vol. 33, No. 9, 2000, pp. 552-558. doi:10.1007/BF02480535

[63] H. Kada, M. Lachemi, N. Petrov, O. Bonneau and P.-C. Aitcin, "Determination of the Coefficient of Thermal Expansion of High Performance Concrete from Initial Setting," Materials and Structures, Vol. 35, No. 1, 2002, pp. 35-41. doi:10.1007/BF02482088

[64] C. S. Poon, S. C. Kou and L. Lam, "Pore Size Distribution of High Performance Metakaolin Concrete," Journal of Wuhan University of Technology-Mater. Sci. Ed., Vol. 17, No. 1, 2002, pp. 42-46.

[65] C.-S. Jiang, L.-N. Lu, S.-B. Guan, Q.-J. Ding and S.-G. 
$\mathrm{Hu}$, "Preparation of High Performance Non-Dispersible Concrete," Journal of Wuhan University of TechnologyMater. Sci. Ed., Vol. 19, No. 2, 2004, pp. 67-69

[66] Z. H. Pan, F. Hiromi and T. H. Wee, "Preparation of High Performance Foamed Concrete from Cement, Sand and Mineral Admixtures," Journal of Wuhan University of Technology-Mater. Sci. Ed., Vol. 22, No. 2, 2007, pp. 295-298. doi:10.1007/s11595-005-2295-4

[67] J. F. Lü, H. Guan, W. X. Zhao and H. J. Ba, “Compressive Strength and Permeability of High-Performance Concrete," Journal of Wuhan University of Technology-Mater. Sci. Ed., Vol. 26, No. 1, 2011, pp. 137-141.

[68] P. Montes, W. Theodore and B. F. Castellanos, "Interactive Effects of Fly Ash and CNI on Corrosion of Reinforced High-Performance Concrete," Materials and Structures, Vol. 39, No. 2, 2006, pp. 201-210. doi:10.1617/s11527-005-9026-3

[69] E. Guneyisi and M. Gesoglu, "A Study on Durability Properties of High-Performance Concretes Incorporating High Replacement Levels of Slag," Materials and Structures, Vol. 41, No. 3, 2008, pp. 479-493. doi:10.1617/s11527-007-9260-y
[70] G. C. Cordeiro, R. D. T. Filho and E. M. Rego Fairbairn, "Use of Ultrafine Rice Husk Ash with High-Carbon Content as Pozzolan in High Performance Concrete," Materials and Structures, Vol. 42, No. 7, 2009, pp. 983-992. doi:10.1617/s11527-008-9437-Z

[71] O. Mazanec, D. Lowke and P. Schie, "Mixing of High Performance Concrete: Effect of Concrete Composition and Mixing Intensity on Mixing Time," Materials and Structures, Vol. 43, No. 7, 2010, pp. 357-365. doi:10.1617/s11527-009-9494-y

[72] S.-D. Hwang, K. H. Khayat and D. Youssef, "Effect of Moist Curing and Use of Lightweight Sand on Characteristics of High-Performance Concrete," Materials and Structures, Vol. 46, No. 1-2, 2013, pp. 35-46. doi:10.1617/s11527-012-9881-7

[73] P. C. Aitcin, "High-Performance Concrete," Taylor \& Francis e-Library, 2004.

[74] K. Chinnaraju, K. Subramanian and S. R. R. Senthilkumar, "Strength Properties of HPC Using Binary, Ternary and Quaternary Cementitious Blends," Structural Concrete, Vol. 11, No. 4, 2010, pp. 191-198. doi:10.1680/stco.2010.11.4.191 